\title{
Linking landscape attributes to salmon and decision-making in the southern Kenai Lowlands, Alaska, USA
}

\author{
Coowe M. Walker $^{1,2}$, Dennis F. Whigham $^{3}, \underline{\text { I. Syverine Bentz }}{ }^{1,2}$, Jacob M. Argueta $^{1,2}$, Rvan S. King $^{4}$, Mark C. Rains $^{5}$, Charles A. \\ Simenstad $^{6}$, Chris Guo $^{1,2}$, Steven J. Baird ${ }^{1,2}$ and Conrad J. Field $^{1,2}$
}

\begin{abstract}
While Pacific salmon are economically and culturally important worldwide, Alaska, USA is one of the few remaining places on earth where sustainable management of salmon is possible, even in the face of wide-ranging threats, including overharvesting and the impacts of climate change. A continuing challenge that we face is to understand the ecological processes that result in sustainable salmon populations and report that science to stakeholders in a way that promotes decision-making to avoid the destruction of salmon populations that has occurred in most areas of the lower 48 states. To address this challenge, our studies in the southern Kenai Lowlands of Alaska are designed to understand the ecological linkages between the landscape and salmon-bearing streams. Our focus on headwater streams that are essential habitat for juveniles of several salmonids demonstrates multiple connections between uplands, wetlands, and the headwater streams. These ecological linkages have been mapped across the watersheds of the southern Kenai Lowlands and used to create spatial tools for communicating with stakeholders who are making land-use decisions that affect salmon-supporting habitats. We present how the main findings of our research, i.e., the influence of alders, peatlands, and groundwater flows on riparian and headwater streams, were incorporated into a spatial tool that was used in case studies with user groups and in outreach efforts. We include evidence that these efforts to engage with stakeholders are resulting in attitudinal shifts as well as on-the-ground changes in peoples' decision-making.
\end{abstract}

Key Words: Alaska; communities; conservation; salmon; sustainability; watersheds

\section{INTRODUCTION}

The world is full of examples of coastal landscapes that have been so altered that degradation of aquatic resources has required enormous financial efforts to restore them to an earlier condition or to halt the degradation (Duarte et al. 2015, Abdou et al. 2016, Elliott et al. 2016, Tanacredi et al. 2016, Canuel et al. 2017, Zedler 2017). In Canada and the lower 48 U.S. states, habitat loss and disturbance have had significant long-term negative impacts on downstream and estuarine resources, including salmon populations (Simenstad et al. 1982, Murphy 1995, McClure et al. 2008, Bisson et al. 2009, Waples et al. 2009, Fleming et al. 2014, David et al. 2016, Schoen et al. 2017). In contrast, most of the landscapes that support salmon in Alaska have not been degraded. However, the effects of climate change on important environmental factors such as stream temperature and flows (Leppi et al. 2014, Callahan et al. 2015, Mauger et al. 2017), plus increased human activities and development around salmonbearing rivers and headwater streams, portend problems in the future for the continued resilience of salmon (Schoen et al. 2017, Sloat et al. 2017). With information about landscape functions essential to salmonids, stakeholders have the capacity to make informed decisions to preserve the value of salmon resources.

The majority of research on interactions between salmon and their in-stream habitats has focused on the portion of the stream network that is reached by returning adults. Adult salmon are also recognized as an important source of marine-derived nutrients that represent a key component of marine-freshwater linkages (Schmidt et al. 1998, Mitchell and Lamberti 2005, Rinella et al. 2013, Buxton et al. 2015, Samways et al. 2015). The movement of marine-derived nutrients to adjacent riparian habitats in the form of salmon carcasses is another important component of landscape linkages in lower river reaches (Vizza et al. 2017, Richardson et al. 2017), even moving through food webs to higher trophic levels such as birds (Wagner and Reynolds 2019). Juveniles of some salmonids (e.g., chinook Oncorhynchus tshawytscha, coho $O$. kisutch) may move upstream of areas where adults reproduced (e.g., Rosenfeld et al. 2000, Bryant et al. 2004, Foley et al. 2015, Davis et al. 2016) and may spend significant amounts of time in smaller headwater streams before moving downstream and eventually into the ocean.

Headwater (i.e., first order) streams are integral components of landscapes (see Nadeau and Rains 2007a), accounting for most of the stream length in watersheds (Nadeau and Rains 2007b, Ledesma et al. 2018) and collectively forming a network of hydrologically linked upland and wetland habitats that merge to form higher order streams that eventually discharge into estuarine environments (Alexander et al. 2007, Freeman et al. 2007, Wiplfi et al. 2007). At a smaller scale, headwater streams are part of a continuum of surface and subsurface hydrological flows that link uplands, riparian wetlands, and streams, allowing uplands and riparian wetlands to serve as important sources of nutrients and organic matter, including dissolved carbon, and support stream structure (Dekar et al. 2012, Gracz et al. 2015, Wallace et al. 2015, Lecerf et al. 2016, Ledesma et al. 2016, Callahan et al. 2017, Lidman et al. 2017, Campeau et al. 2018, Little and Altermatt 2018). Headwater streams are also components of transportation corridors for aquatic and terrestrial animals (e.g., Olson and Burnett 2009) that result in landscape-scale linkages (Lamberti et al. 2010). Furthermore, research at a wide range of scales has demonstrated that alteration of the linkages between uplands and headwater streams can alter the patterns of the delivery of water, nutrients, and organic matter to streams (Roberts et al. 2007), with negative consequences, including impacts to aquatic food webs (Gage et al. 2004) and host-parasite relationships (Lagrue

${ }^{1}$ Kachemak Bay National Estuarine Research Reserve, ${ }^{2}$ Alaska Center for Conservation Science, University of Alaska Anchorage, ${ }^{3}$ Smithsonian Environmental Research Center, ${ }^{4}$ Department of Biology, Baylor University, ${ }^{5}$ School of Geosciences, University of South Florida, ${ }^{6}$ University of Washington 
et al. 2018). Following disturbance, the recovery of riparian and stream habitats is possible (Kozlowski et al. 2016) but depends on factors such as the spatial characteristics of the disturbance (e.g., Guzy et al. 2019). Recovery is often slow (e.g., Hasselquist et al. 2015, Warren et al. 2016), with full recovery depending on whether all elements of the upland-riparian-stream continuum have been restored (Muller et al. 2016).

Our study focuses on the four largely unimpaired, nonglacial watersheds of the southern Kenai Lowlands, Alaska, USA, which collectively comprise $9400 \mathrm{~km}^{2}$ (Fig. 1). These watersheds support salmon that underpin robust commercial and sport salmon fisheries valued at more than USD $\$ 80$ million per year on the Kenai Peninsula (Carson et al. 2009, ADFG 2019). In addition to the dependence on salmon as an economic mainstay, coastal communities on the Kenai Lowlands rely on salmon as an important local food source and cultural touchstone. Reverence for and dependence on salmon have been at the center of traditional and contemporary livelihoods of the Indigenous peoples of the Kenai Lowlands region. The Kachemak Alaska Native tradition and the Kahtnuht'ana Dena'ina, Athabascan peoples, whose descendants inhabit the Kenai Peninsula, have thousands of years of history and culture surrounding salmon (Workman and Workman 2010). Non-Native Alaskans also value salmon highly (KBNERR and NOAA 2001, Flaherty et al. 2019).

Fig. 1. Map showing the location of the Kenai Lowlands region on the southern end of the Kenai Peninsula in south-central Alaska, USA. The region encompasses four major watersheds, indicated by the four different colors.

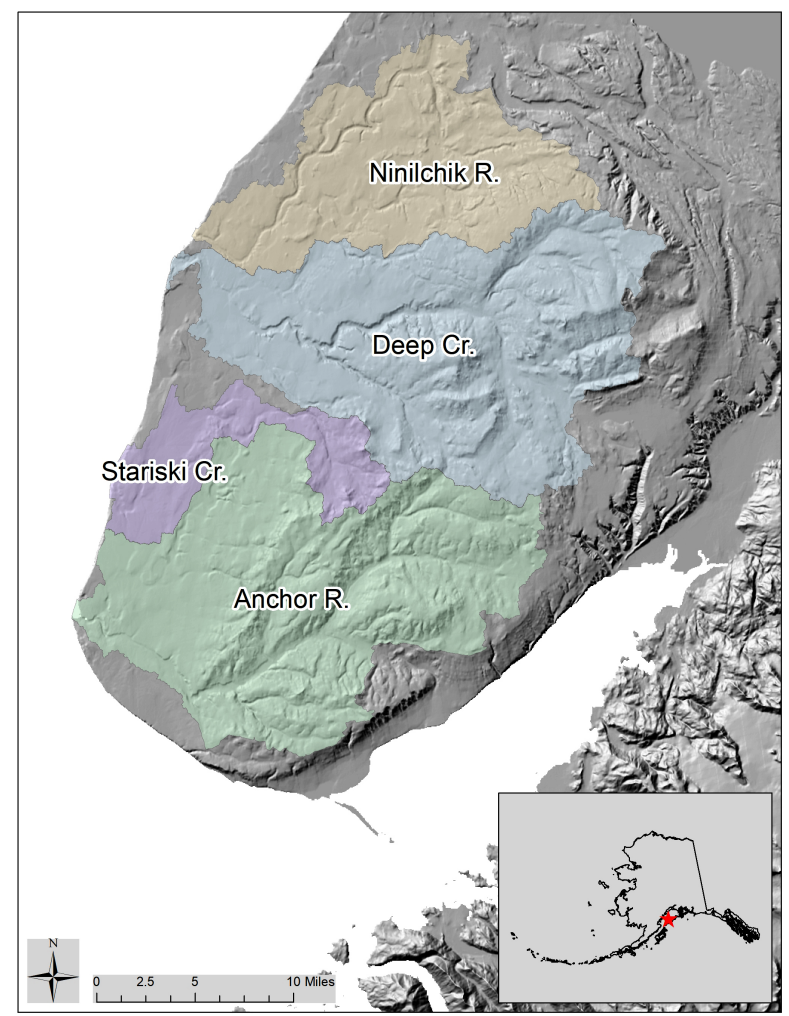

Although most people in the Kenai Lowlands value and feel strongly about salmon, these feelings do not necessarily translate into salmon-friendly land-use strategies in landscapes consisting of a complex web of public and private land ownership. More than $80 \%$ of the lands of the southern Kenai Lowlands are in private land ownership (Fig. 2). A complicating factor in any management strategy is that streams that provide salmon habitats most often pass through watersheds with multiple stakeholders. A further complicating factor in any management strategy is that stakeholders and streams both share the same limiting resources such as groundwater. Thus, maintaining the natural capital of salmon-rich ecosystems will require land-use decisions made by all stakeholders.

Fig. 2. Map showing the headwater streams (yellow) of the Kenai Lowlands region, Alaska, which compose a large proportion of the stream networks and are largely unprotected from development. Only a small proportion of the landscape has protected status (green), and much of the area is already platted, but not yet developed.

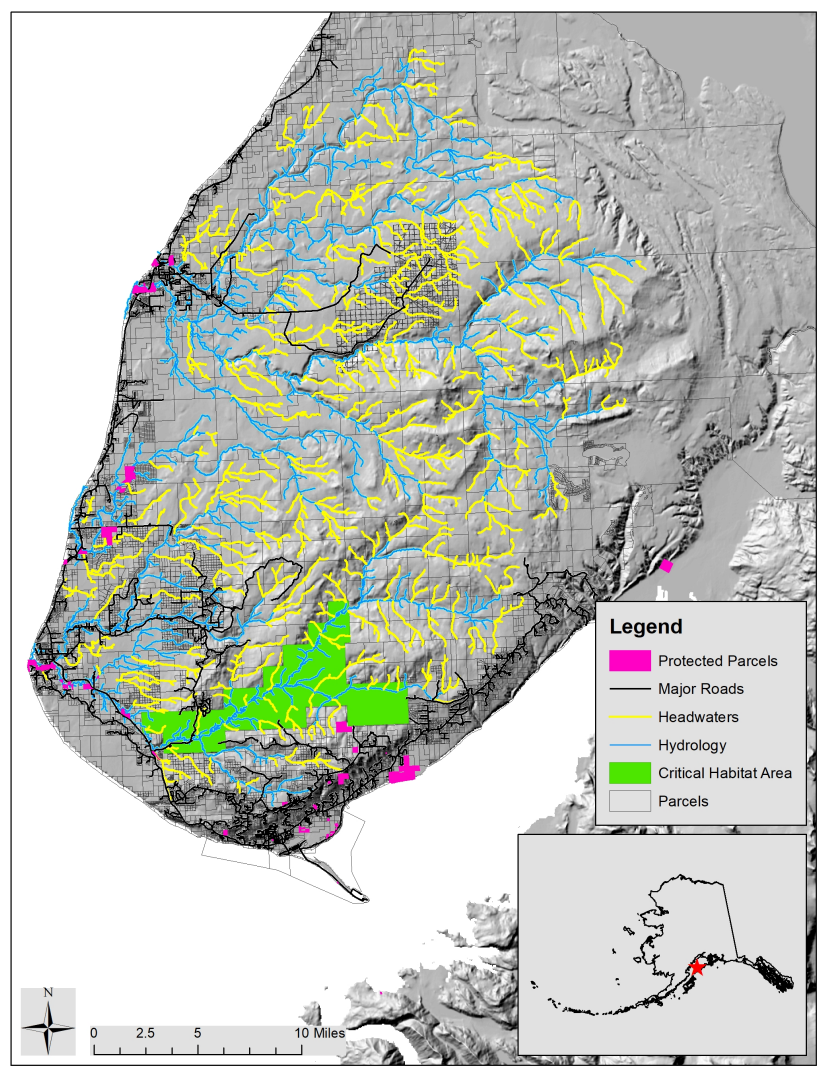

Through a long-term collaborative effort (i.e., since 2006 and ongoing), researchers with expertise in fisheries, aquatic productivity, landscape drivers of stream systems, wetland ecology, and groundwater have been working with the Kachemak Bay National Estuarine Research Reserve (KBNERR) on a series of studies elucidating connections between landscape elements, watersheds, stream productivity, and salmon in the southern Kenai Lowlands. KBNERR provides a place-based platform and 
Fig. 3. Conceptualized drawing of the connections between surrounding landscapes and headwater stream juvenile salmon habitat. The drawing provides a visual summary of the scientific concepts and is useful for outreach and communications. Key references from State of Alaska Salmon and People Kenai Lowlands Workgroup studies are also listed.

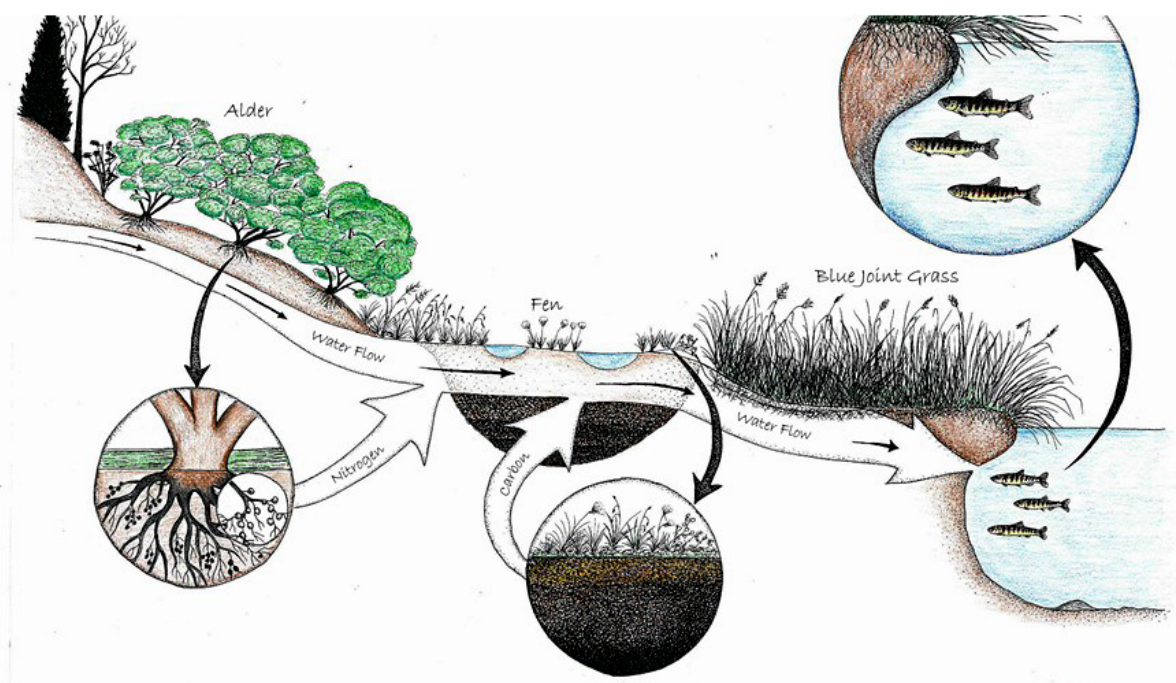

\begin{tabular}{|l|l|}
\hline Studies on landscape linkages to headwater stream functions, in the southem Kenai Lowlands by chronological order. \\
\hline Shaftel et al. 2011 & Hiatt et al. 2017 \\
\hline Shaftel et al. 2012 & Callahan et al. 2015 \\
\hline Dekar et al. 2012 & Callahan et al. 2017 \\
\hline King et al. 2012 & Whigham et al. 2017 \\
\hline Walker et al. 2012 & Robbins et al. 2017 \\
\hline Whigham et al. 2012 & Robbins et al. 2020 \\
\hline
\end{tabular}

serves as a local host and convener for regional research and stakeholder engagement. Following is a summary of major research findings on landscape linkages to salmon, the process used to engage stakeholders with the science, and the results of those activities. We end with a view toward the future, which includes additional focal research topics and collaborative engagement opportunities.

\section{LOCAL RESEARCH, TOOL DEVELOPMENT, AND STAKEHOLDER ENGAGEMENT}

In 2006, when our collaborative effort began, most headwater streams in the southern Kenai Lowlands were not yet recognized as salmon habitat. Through initial investigations, we realized that these headwaters are supporting abundant populations of juvenile salmonids, and this realization prompted a series of focused studies demonstrating linkages along the uplandriparian-headwater stream continuum that support salmon rearing. These investigations have built understanding of how landscape elements such as alders, peatlands, and groundwater flows influence salmon-rearing habitats (Fig. 3).

Initial investigations (2005-2007) resulted in a validated model for predicting fish density, distribution, and composition based on landscape characteristics of the four rivers of the southern Kenai Lowlands, revealing that headwater streams of the region supported $\geq 250,000$ juvenile chinook salmon, coho salmon, and Dolly Varden char (Salvelinus malma; King et al. 2012). This model identified catchment topography as the strongest driver of headwater stream physical, chemical, and biological condition by establishing the physical template that controlled stream velocity and channel morphology, which in turn govern water quality, distributions of macroinvertebrates and juvenile salmonids, and the type and amount of wetlands (King et al. 2012, Walker et al. 2012, Whigham et al. 2012).

We also documented that the proportion of alder cover in a headwater stream watershed significantly affects the concentration of inorganic nitrogen in stream water and has a strong controlling influence on stream nitrogen, stream food webs, juvenile salmon diets, and vegetation in riparian habitats. Inputs were primarily through spring melt and groundwater flows (Shaftel et al. 2011, Dekar et al. 2012, Walker et al. 2012, Callahan et al. 2017, Hiatt et al. 2017, Whigham et al. 2017). Alder roots have nodules that contain bacteria (Frankia spp.) that fix atmospheric nitrogen $\left(\mathrm{N}_{2}\right)$ and make it available for use by the plant. The nitrogen is released and transported along hydrological flow paths when leaves and roots senesce. Nitrogen transported to streamside wetlands then enhances primary productivity (Callahan et al. 2017, Whigham et al. 2017) and nitrogen levels in plant tissues, leading to faster rates of litter decomposition (Shaftel et al. 2012, Whigham et al. 2017). The products of decomposition then enter the stream food chain. Isotope studies reveal that $>60 \%$ of the nitrogen in juvenile coho salmon and Dolly Varden tissue has a terrestrial origin, providing clear evidence of the linkage between watersheds and headwater streams and confirming the importance of alder in the overall dynamics of headwater streams (Dekar et al. 2012; Fig. $3)$. 
Approximately one-half of the landscape of the southern Kenai Lowlands is covered by peatland fens (Gracz and Regan 2005), which results in particulate and dissolved carbon export to streams. Areas with both abundant peatlands and alder (nitrogen and carbon inputs) represent landscape hotspots, and those stream reaches have higher production and support higher densities of macroinvertebrates and juvenile fish than other stream reaches (Robbins et al. 2017, 2020). Investigations of the effects of headwater stream nutrients exported downstream to lower river reaches consistently show that nitrogen and carbon originating in headwater stream watersheds are being transferred downstream, fueling food webs of lower river reaches.

Groundwater discharge is important for supporting stream flows, modulating stream temperatures, and delivering nutrients (Callahan et al. 2015, 2017). The temperature effect persists for many kilometers downstream, especially in watersheds with steep valley and stream gradients (Callahan et al. 2015). This effect is especially important for juvenile fish in the winter because the warmer groundwater entering streams enable fish to find refuges where the water does not freeze. The now obvious critical role played by groundwater is initiating new studies related to groundwater vulnerability and sustainability in terms of both human and nonhuman users.

Studies have also documented effects of ongoing climate change. The southern Kenai Lowlands have been the epicenter of a long spruce bark beetle outbreak that has culled 1.6 million ha of trees in south-central Alaska and resulted in deforestation, with subsequent unprecedented grassland fires, starting in 2005. Available water in this area has declined by at least 55\% since 1968 (Berg et al. 2009), and recently, alder sawfly, a new exotic invasive species, has caused large-scale defoliation of thin-leaf alder ( $A$ lnus tenuis; Roon et al. 2018). There also is evidence of long-term drying of the region's wetlands, although the reasons and implications remain unclear (Klein et al. 2005).

Collectively, these studies form a strong foundation of spatially explicit information that has the potential to be useful in proactive decision-making. However, while reporting on the relevance of surrounding landscapes to salmon stream habitat in scientific publications is important, it is insufficient when the desired outcome is landscape management that will result in continued sustainability of salmon populations. Therefore, although there are additional research needs, we have also focused on communicating the available science to promote and support stakeholder engagement and decision-making. The following sections are devoted to describing the State of Alaska Salmon and People Kenai Lowlands Workgroup's (KL-SASAP) efforts to guide stakeholder engagement around this body of research.

\section{METHODS FOR ENGAGING WITH STAKEHOLDERS}

Our engagement strategy was rooted in the fact that salmon habitats in the southern Kenai Lowlands are largely intact, and that the people of the region value and feel strongly about salmon (e.g., Earth Economics 2013, Schwörer 2014, Flaherty et al. 2019; The Salmon Project, https://salmonproject.org/about/). Long term place-based commitment to science that is responsive to stakeholder needs and ongoing active engagement and evaluations enables KBNERR to function as a boundary institution by providing an interface between science and stakeholders (Cash and Moser 2000, Carr and Wilkinson 2005,
Bednarek et al. 2016). Though it may seem obvious that people need to be part of any sustainable salmon strategy, the explicit recognition that people are integral parts of the ecosystem lays the groundwork for decision-making approaches that are more likely to succeed (Palmer et al. 2004).

Decision-making strategies that benefit salmon are complicated in the southern Kenai Lowlands because streams that provide salmon habitats most typically pass through parcels of land with multiple public and private stakeholders (Fig. 2), including present and absentee private-property owners. Where stream protections do exist, they are generally limited to the stream itself, and there is very little awareness that immediately adjacent riparian areas and associated landscapes are important to maintaining salmon populations. One of the few sources of protection is the state's Anadromous Waters Catalog, which requires that water bodies must be documented as supporting some life function of an anadromous fish species (Alaska Statutes 16.05.871), typically spawning, rearing, or migration. So far, through KBNERRs headwater stream research efforts, $>167 \mathrm{~km}$ of headwaters have been added to the Anadromous Waters Catalog. Nomination and recognition of anadromous stream reaches in the Anadromous Waters Catalog provides some protection within $32 \mathrm{~m}$ horizontal of the channel by the local anadromous waters habitat protection district (Kenai Peninsula Borough Code 21.18.040). However, protecting riparian buffers of any distance is a regular matter of debate by policy makers in the Kenai Lowlands. Furthermore, recent surveys indicate that fewer than $20 \%$ of anadromous streams allow for adequate fish passage, and many culvert replacements are being planned as a result (Kenai Watershed Forum culvert assessment, https:// kenaiwatershed.org/science-in-action/fish-barriers/culvert-assessment/). Steady population growth in the region could lead to considerable land-use changes affecting streams and watersheds (KBNERR and NOAA 2001, City of Homer 2018, ADLWD 2020). Thus, the future of productive and resilient salmon populations, particularly on lands that lack state or federal conservation status, will require collaborative decision-making (Vasslides and Jensen 2016). There is a pressing need to determine what circumstances and communication strategies give science an effective voice in decision-making (Beechie et al. 2009).

Most human-salmon interactions take place through fishing activities for adult salmon in lower river reaches, estuarine, nearshore, and ocean environments. However, people live in upper watershed regions where juvenile salmon are rearing, and in many cases, are unaware that the parcels of land that they live on may be directly connected to a salmon-bearing stream. Given that seemingly remote land-use practices can alter a stream's supportive qualities for salmon, the problem becomes one of conveying this issue to an amalgam of unaware audiences.

The KL-SASAP brought stakeholders and decision makers into common conversation about how to make research more accessible for land-use decisions that promote salmon resilience. KL-SASAP began with a steering committee of researchers, who had developed the body of science on how landscapes and streams are connected, which envisioned how the data could contribute to creating a spatial data tool identifying key landscape support elements. The goal was to develop a tool that provided a bridge between the scientific research and multistakeholder decisionmaking for watershed management. 
Fig. 4. Example maps from the spatial tool, which puts human activities such as ownership, roads, buildings, etc. in the context of landscape ecosystem support for salmon stream productivity, such as shallow groundwater flows, alder patches, and peatlands. The tool is used for case studies with regional stakeholders such as farmers interested in siting agricultural practices to avoid disruption of landscape support for salmon streams.
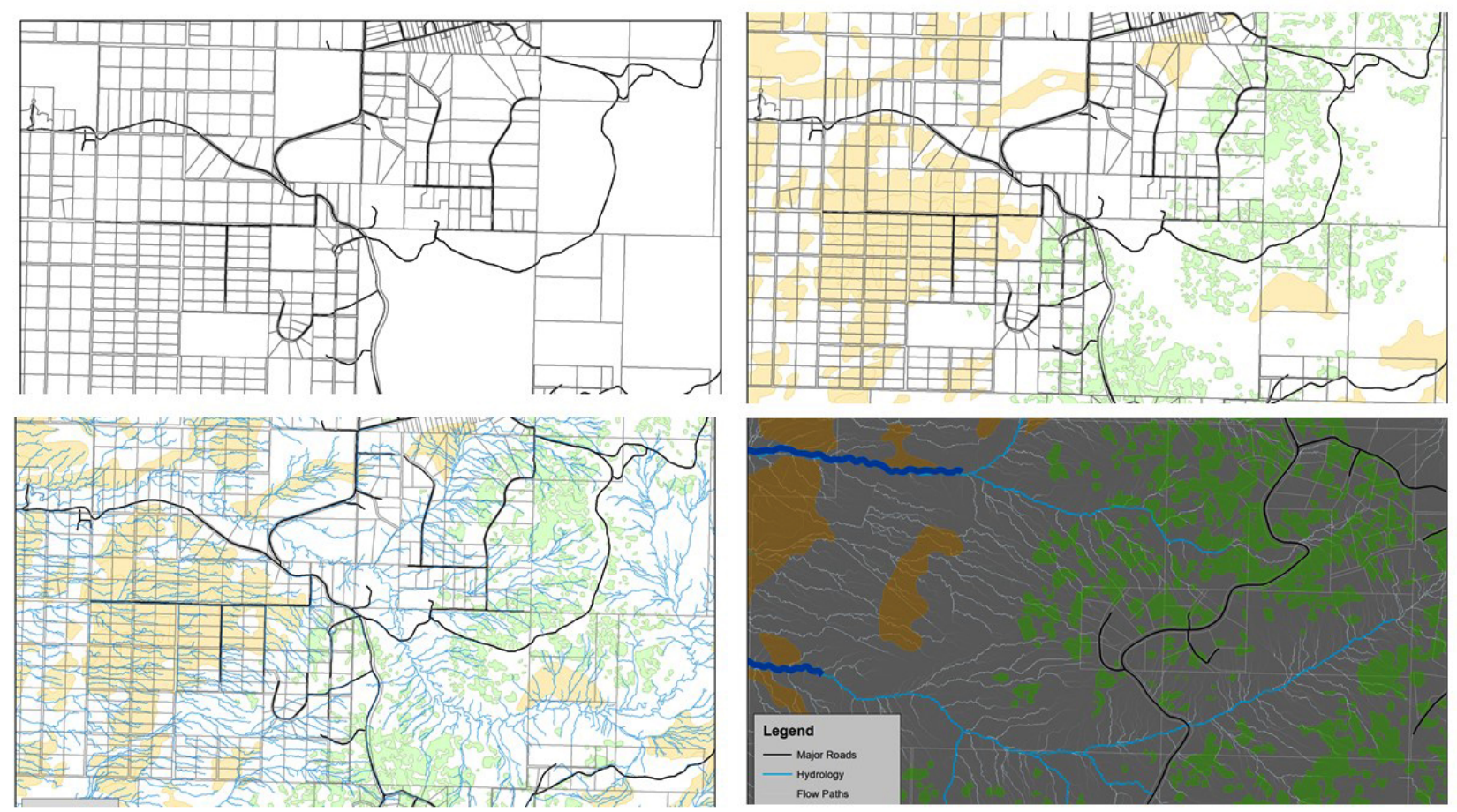

KL-SASAP first conducted a stakeholder analysis to identify organizations or individuals who: (1) had additional knowledge or skills, (2) are or would be directly affected, (3) had decisionmaking authority or influence, (4) would be implementing results or outcomes, (5) might oppose or derail the process, and (6) would actively support the process. The identified stakeholders included people with permit and regulatory review authority (i.e., regulators and managers from the borough, state, and federal governments), elected and appointed officials, conservation leaders, Alaskan Native leaders and land managers, and communication specialists. Individuals with these affiliations were invited to join the KL-SASAP initiative and to codesign an effective participatory process. They were asked for information about their interests or concerns, their positions or desired outcomes from the workgroup, their level of influence, and their potential level of involvement. The group met for three week-long collaborative workshops over an 18-month period, culminating in a public workshop at the Kachemak Bay Science Conference in 2018.

A spatial GIS-based tool was developed to integrate the portfolio of landscape elements that research has identified as important to salmon stream support (shallow groundwater flow paths, peat wetlands, alder patches in headwater stream watersheds), relative to anadromous streams, parcel boundaries, and existing developments (roads, buildings, etc.; Fig. 4). Geospatial layers representing each of the landscape elements were imported into
ArcMap and overlaid against anadromous streams, parcel boundaries, and satellite imagery. Parcels can be thus be examined on an individual scale, allowing the user to understand landscape connectivity on a fine scale. Incorporating this tool into land-use decision-making aids in visualizing and quantifying often intangible yet critical landscape elements and connections.

Each of the geospatial layers were sourced from different efforts and projects. Alder polygons were hand digitized in ArcMap using imagery acquired by the Ikonos and Quickbird satellites in 2003. Ground-truthing of alder stands was accomplished by Shaftel et al. (2011). The majority of alder mapped in the 2011 study consisted of green alder (Alnus viridis ssp. fruticosa) and Sitka alder (Alnus viridis ssp. sinuata).

The peatland layer used in the geospatial tool was a subset of the Gracz wetland classification of the Kenai Peninsula (Gracz and Regan 2005). Classification of Peninsula wetlands is largely based on hydrological and geomorphological factors. Wetlands were delineated using stereo-paired aerial imagery captured in 2005 and 2006. Between 2008 and 2013, wetland classes were groundtruthed and soil profiles described (Gracz and Regan 2005).

Flow paths were delineated in ArcMap using the flow accumulation and flow direction tools. The digital elevation model used in this process was derived from LiDAR acquired in 2008. Shallow groundwater flow has been shown to follow surface topography; thus, high-resolution elevation models are adequate 
Table 1. Stakeholder engagement opportunities, key interests, products of interest, and desired outcomes in the Kenai Lowlands region, Alaska, USA.

\begin{tabular}{|c|c|c|c|c|c|c|}
\hline Organization & $\begin{array}{l}\text { Stakeholder } \\
\text { category }\end{array}$ & $\begin{array}{l}\text { Stakeholder } \\
\text { interests }^{\dagger}\end{array}$ & $\begin{array}{l}\text { Stakeholder } \\
\text { perspectives }^{\dagger}\end{array}$ & $\begin{array}{l}\text { Products of } \\
\text { interest }\end{array}$ & $\begin{array}{c}\text { Stakeholder vision for } \\
\text { outcome (desired outputs) }\end{array}$ & $\begin{array}{c}\text { Key issues to be } \\
\text { addressed (potential } \\
\text { challenges or conflicts) }\end{array}$ \\
\hline $\begin{array}{l}\text { Soil and } \\
\text { Water } \\
\text { Conservation } \\
\text { District }\end{array}$ & Quasi-government & $\begin{array}{l}\text { Agricultural } \\
\text { production, other } \\
\text { soil and water uses }\end{array}$ & $\begin{array}{l}\text { Explore incentives or } \\
\text { practices through } \\
\text { established frameworks, } \\
\text { agricultural easements }\end{array}$ & $\begin{array}{l}\text { video, story } \\
\text { map, data layers }\end{array}$ & $\begin{array}{l}\text { Static map of } \\
\text { subwatersheds with } \\
\text { functions, best practices, } \\
\text { serve and update tools and } \\
\text { information }\end{array}$ & $\begin{array}{l}\text { Divergent cultural or } \\
\text { mental models }\end{array}$ \\
\hline Land Trust & $\begin{array}{l}\text { Nongovernmental } \\
\text { organization }\end{array}$ & Salmon habitat & $\begin{array}{l}\text { Prioritization and } \\
\text { justification of land } \\
\text { acquisition, } \\
\text { communication of } \\
\text { scientific findings, } \\
\text { demonstrate value }\end{array}$ & $\begin{array}{l}\text { video, story } \\
\text { map, data layers }\end{array}$ & $\begin{array}{l}\text { Identification of hotspots, } \\
\text { serve and update tools and } \\
\text { information on website, } \\
\text { communication and } \\
\text { outreach tools }\end{array}$ & $\mathrm{n} / \mathrm{a}$ \\
\hline Regulator & $\begin{array}{l}\text { Federal } \\
\text { government }\end{array}$ & $\mathrm{n} / \mathrm{a}$ & $\mathrm{n} / \mathrm{a}$ & video, story map & $\begin{array}{l}\text { Use to train new staff or } \\
\text { people unfamiliar with the } \\
\text { region }\end{array}$ & $\mathrm{n} / \mathrm{a}$ \\
\hline $\begin{array}{l}\text { Land owner } \\
\text { and } \\
\text { manager }\end{array}$ & $\begin{array}{l}\text { Native } \\
\text { corporation }\end{array}$ & $\begin{array}{l}\text { Applications for } \\
\text { managing land use } \\
\text { such as grazing } \\
\text { leases, material sites }\end{array}$ & $\begin{array}{l}\text { Increase value, manage } \\
\text { heritage assets }\end{array}$ & data layers & $\begin{array}{l}\text { Isolate owned or managed } \\
\text { lands, identify salmon } \\
\text { productivity areas }\end{array}$ & $\begin{array}{l}\text { Land access for } \\
\text { researchers, regulatory } \\
\text { permits on owned lands }\end{array}$ \\
\hline $\begin{array}{l}\text { Resource } \\
\text { consultant }\end{array}$ & Private & $\begin{array}{l}\text { Gravel extraction } \\
\text { permits, ease of } \\
\text { access to sites }\end{array}$ & $\begin{array}{l}\text { Efficiencies in } \\
\text { permitting, durability of } \\
\text { access roads }\end{array}$ & data layers & $\mathrm{n} / \mathrm{a}$ & $\begin{array}{l}\text { Some ecologically } \\
\text { important areas have } \\
\text { high monetary values } \\
\text { associated with } \\
\text { extraction }\end{array}$ \\
\hline $\begin{array}{l}\text { Real estate } \\
\text { developers }\end{array}$ & Private & $\begin{array}{l}\text { Property value, } \\
\text { protecting clients } \\
\text { interests in specific } \\
\text { land parcels }\end{array}$ & $\mathrm{n} / \mathrm{a}$ & story map & $\begin{array}{l}\text { Ease of use and } \\
\text { interpretation, educational } \\
\text { to the public }\end{array}$ & $\mathrm{n} / \mathrm{a}$ \\
\hline $\begin{array}{l}\text { Land owner } \\
\text { and } \\
\text { manager }\end{array}$ & $\begin{array}{l}\text { Regional } \\
\text { government }\end{array}$ & $\begin{array}{l}\text { Incorporation of } \\
\text { important } \\
\text { landscape elements }\end{array}$ & $\begin{array}{l}\text { Acquisition, } \\
\text { management and } \\
\text { classification of lands, } \\
\text { disposal of real property } \\
\text { and resources }\end{array}$ & $\begin{array}{l}\text { video, story } \\
\text { map, data layers }\end{array}$ & $\begin{array}{l}\text { Use in land classification, } \\
\text { protperty disposal, or } \\
\text { conservation }\end{array}$ & Water mangement \\
\hline Regulator & $\begin{array}{l}\text { Regional } \\
\text { government }\end{array}$ & $\begin{array}{l}\text { Protect a public } \\
\text { resource, i.e., } \\
\text { salmon spawning } \\
\text { and rearing habitat }\end{array}$ & $\begin{array}{l}\text { Provide permits and } \\
\text { information for access } \\
\text { and limited vegetation } \\
\text { removal }\end{array}$ & $\begin{array}{l}\text { video, story } \\
\text { map, data layers }\end{array}$ & $\begin{array}{l}\text { Use spatial tool with permit } \\
\text { applications, provide video } \\
\text { and story map to applicants } \\
\text { for education }\end{array}$ & $\mathrm{n} / \mathrm{a}$ \\
\hline $\begin{array}{l}\text { Commercial } \\
\text { fisher } \\
\text { organization }\end{array}$ & Private & Educating fishers & $\begin{array}{l}\text { Educated members are } \\
\text { more effective at } \\
\text { decision-making that } \\
\text { supports the salmon } \\
\text { industry }\end{array}$ & $\begin{array}{l}\text { Field trips, data } \\
\text { layers }\end{array}$ & $\begin{array}{l}\text { Use field trips to build } \\
\text { understanding, use data } \\
\text { layers to identify key lands } \\
\text { for potential conservation } \\
\text { measures }\end{array}$ & $\mathrm{n} / \mathrm{a}$ \\
\hline $\begin{array}{l}\text { Regional } \\
\text { school }\end{array}$ & $\begin{array}{l}\text { Native Alaskan } \\
\text { school }\end{array}$ & $\begin{array}{l}\text { Educating } \\
\text { community } \\
\text { members }\end{array}$ & $\begin{array}{l}\text { Learning about } \\
\text { landscape support for } \\
\text { salmon will assist with } \\
\text { community land-use } \\
\text { decisions }\end{array}$ & $\begin{array}{l}\text { Field trips, } \\
\text { videos }\end{array}$ & $\begin{array}{l}\text { Use field trips to build } \\
\text { awareness in children who } \\
\text { can share with their parents } \\
\text { and elders }\end{array}$ & $\mathrm{n} / \mathrm{a}$ \\
\hline
\end{tabular}

in modeling flow paths. All GIS processing of groundwater flow paths was done at KBNERR.

Participants in the workshops emphasized the need for outreach and communication products that could be used to build understanding of not just the science, but also the role of people in the Kenai Lowlands. Responding to this request, videos and story maps were created as mechanisms for introducing the spatial tool or as stand-alone education products (Argueta 2018, Argueta et al. 2018). KL-SASAP then used this suite of products (videos, story maps, and the spatial data tool) to develop and present case studies with specific stakeholder interests who have influence on land-use planning and decision-making. Managers of large land tracts, including governments, tribal land management groups, and organizations that serve as liaisons for diverse landowners, were engaged to test the tools and understand specific uses and decision-making frameworks (Table 1).

Case studies were accomplished by meeting with individuals or teams from identified organizations in familiar settings. Many of the large land owners, land managers, and regulatory stakeholders for the southern Kenai Lowlands are in offices located far from 
the region. To make it easier for the stakeholders to engage, we travelled to their offices for case study meetings, sometimes as far away as $400 \mathrm{~km}$. Case studies with local stakeholders were typically discussed at the KBNERR office. Each case study involved showing stakeholders the video and story map and subsequently engaging with the spatial tool by asking the stakeholders for their specific location, scale, and management decision or need. We navigated the spatial tool to their chosen property and discussed the landscape salmon-support elements that were present, possible decision-making scenarios, and potential effects on salmon productivity (Fig. 4). Results included both short-term outputs (products and applications such as workgroup meetings, outreach visuals, videos, story maps, the spatial tool, and case studies) and longer term outcomes (changes in relationships, mindsets, and approaches).

\section{RESULTS OF STAKEHOLDER ENGAGEMENT}

Interactively exploring the spatial tool with stakeholders during the case studies provided a focus for understanding the scope of stakeholder interests and needs, resulting in improved capacity to match the scales of biogeophysical systems with scales of management systems and decision-making frameworks (Cash and Moser 2000). The value of videos, schematics, and illustrations was clear in all the case studies. People were able to engage with the visual material as an entry point into the more technical information, and, in some cases, permitters and regulators found the visual material to be helpful as educational tools for both their clients and new staff, who needed to become familiar with the concerns of the area quickly. Having the curated information based on stakeholder needs and level of expertise provided flexibility and breadth of communications. We found that meeting people in their decision-making framework (i.e., at their office or site) and understanding their priorities facilitated the ease and acceptance of the information.

Outcomes emerged over a long time frame and prolonged commitment to engagement (Fig. 5). Two years following the initial engagements, there are tangible results that were set in motion through the case studies. The case studies created an opportunity to build relationships, as well as to share information collaboratively. For example, the case studies with the Kachemak Heritage Land Trust led to the idea of bringing commercial fishers into the field to learn about landscape support for juvenile salmon. Kachemak Heritage Land Trust and KBNERR developed a collaborative field-based learning opportunity called Fish Need Land Too, which involves bringing members of the commercial fishing community into the watershed with researchers to catch juvenile salmon in headwater streams and talk about the science and conservation needs for watersheds (Fig. 6). Many of the field trip participants had never seen juvenile salmon or considered the importance of the freshwater or estuarine phase of their life history. As a direct result of one of these field trips, the North Pacific Fisheries Association volunteered to purchase land to protect juvenile salmon habitat. This is a dramatic and encouraging example of how engaging stakeholders with science that has a direct connection to their lives results in meaningful outcomes.

Incorporating science into policy outcomes is a more difficult but more meaningful end result. In general, there is a low tolerance for regulations in Alaska. However, many coastal communities
Fig. 5. Flowchart showing the State of Alaska Salmon and People Kenai Lowlands Workgroup workflow and results. The project (inputs) resulted in a suite of products (outputs) that provided the impetus for several meaningful outcomes as well as outcomes that will hopefully emerge over time.

\begin{tabular}{|c|c|c|c|}
\hline \multirow{5}{*}{$\begin{array}{l}\text { Local research } \\
\text { synthesis } \\
\text { Workgroup } \\
\text { Meetings }\end{array}$} & $\begin{array}{l}\text { Spatial tool } \\
\text { Video } \\
\text { Storyman }\end{array}$ & $\begin{array}{l}\text { Land trust conservation } \\
\text { planning and land } \\
\text { purchases }\end{array}$ & $\begin{array}{l}\text { Regional progress } \\
\text { towards tangible } \\
\text { conservation and } \\
\text { restoration actions }\end{array}$ \\
\hline & $\begin{array}{l}\text { Storymap } \\
\text { Case studies } \\
\text { Site based learning }\end{array}$ & $\begin{array}{l}\text { Recommendations for } \\
\text { material site code policy } \\
\text { revisions }\end{array}$ & $\begin{array}{l}\text { Science informed } \\
\text { planning and decision- } \\
\text { making }\end{array}$ \\
\hline & $\begin{array}{l}\text { opportunities } \\
\text { Workshop }\end{array}$ & $\begin{array}{l}\text { Input to Borough } \\
\text { riparian ordinances }\end{array}$ & \multirow{2}{*}{$\begin{array}{l}\text { Increased decision- } \\
\text { making awareness and } \\
\text { understanding of } \\
\text { salmon habitat } \\
\text { vulnerabilities }\end{array}$} \\
\hline & & \multirow{2}{*}{$\begin{array}{l}\text { Input to agricultural } \\
\text { lease initiatives } \\
\text { Scenario planning for } \\
\text { water resources }\end{array}$} & \\
\hline & & & $\begin{array}{l}\text { Improved capacity for } \\
\text { partnering with diverse } \\
\text { organizations }\end{array}$ \\
\hline
\end{tabular}

Fig. 6. Malcom Milne, President of the North Pacific Fisheries Association, holds a viewing tank with juvenile coho salmon caught in the headwater stream that he stands beside during a site-based learning opportunity for commercial fishers.

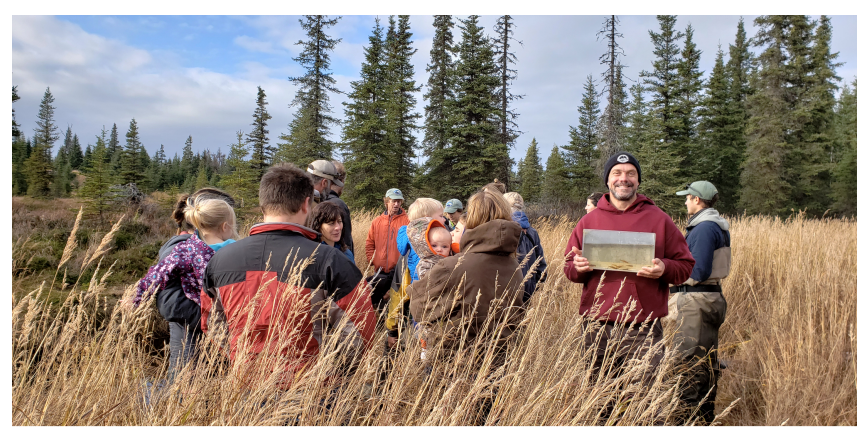

are reliant on resources that might be protected by regulations. Progress toward policies that incorporate ecosystem science can seem painstakingly slow but there is at least some evidence that KL-SASAP outputs are being taken into consideration. For example, the Kenai Borough government that regulates land uses in the southern Kenai Lowlands created a workgroup to review the Material Site Code ordinance, which is primarily focused on gravel mine operations. This workgroup recommended policy revisions that were, in part, based on the outcomes of the KLSASAP spatial tool and outreach. Likewise, Borough staff have asked for presentations about landscape connections to streams that could be relevant to the refinement of riparian buffer ordinance discussions. Unfortunately, policy considerations are often political fodder, and the workgroup policy recommendations were not adopted by the full assembly. Nonetheless, awareness of the science was promoted, and the process of translating science to policy was begun. While it remains to be seen if code revisions 
Table 2. Examples of outcomes leading to progress toward regional conservation efforts from the State of Alaska Salmon and People Kenai Lowlands Workgroup effort.

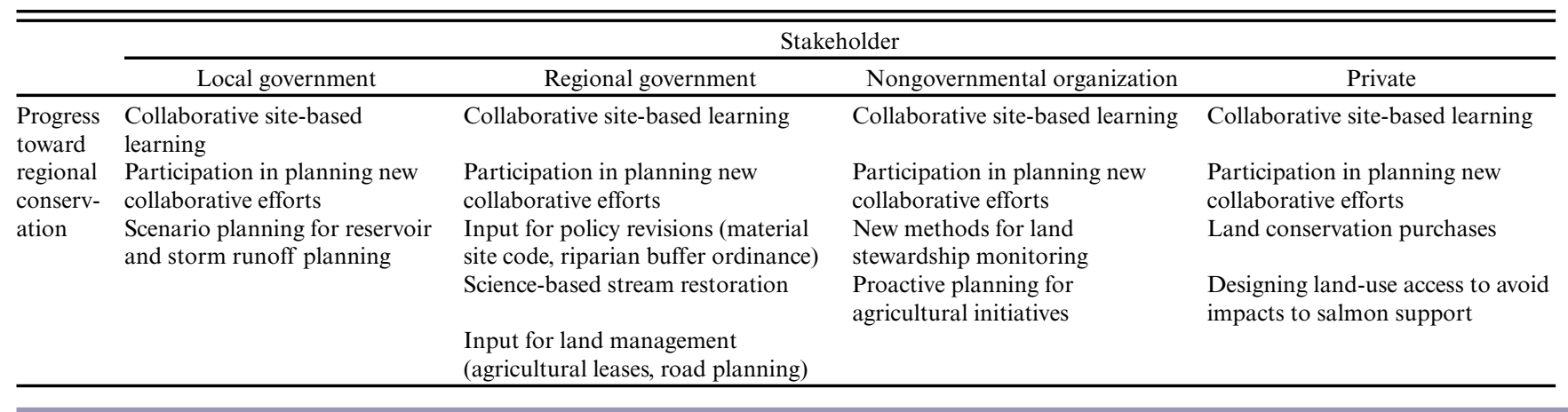

based on science will be accepted as law, the fact that policy conversations are including science about landscape linkages to salmon stream productivity is an indication that progress is being made toward improved decision-making for landscape support of salmon (Table 2).

Building trusted relationships is a powerful outcome and one that can be measured by stakeholder willingness to participate in collaborative efforts (Arnott et al. 2020). Many of our engagement opportunities were with stakeholders who were new to the watershed science of the KL-SASAP. The process of engaging through the workgroup and through case studies resulted in new and lasting communications. Working with Project GRAD (Graduation Really Achieves Dreams), a nonprofit educational program that strives to advance ambitious educational goals in Alaska's most rural and isolated schools as liaisons, we engaged with the rural Alaska Native village of Tyonek. We exchanged visits with high school students from the village school, inviting them to come to the Kenai Lowlands to learn the science of landscape support for salmon, and conversely, KBNERR staff went to Tyonek to work with students, teachers, and community members to learn about juvenile salmon and landscape support in the village (Fig. 7). Two Tyonek high school students worked collaboratively with KBNERR staff to develop their own outreach materials, including a video about salmon and groundwater. The relationship with Tyonek continues with regular visits and planning for future collaborative efforts.

Collaborative projects such as the KL-SASAP are gaining recognition as a successful way for science to be incorporated into decision-making (Arnott et al. 2020). Through collaboration, there is an iterative information flow from researchers to stakeholders and from stakeholders to researchers. KL-SASAP researchers acquired data around ecosystem processes supporting salmon stream habitats and developed the spatial tool and outreach materials that were shared with stakeholders. These stakeholders are now creating knowledge, intelligence, behavior, and outcomes, which are allowing them to evaluate and revise their questions and needs. For example, given the emerging understanding of the importance of groundwater shown through the KL-SASAP spatial tool, stakeholders such as the City of Homer understood that they have a greater need to know more about the limits on their groundwater resources so that they can better balance their needs between human and nonhuman users.
This feedback then prompted researchers with the KL-SASAP to develop a project (funded through a NERR Science Collaborative) to provide data and data products that could be used for decision-making, including a model to predict the location of key seeps and springs that support both human needs (e.g., springs that provide water to the City's reservoir) and ecosystem needs (e.g., springs that modulate flow, temperature, and nutrient concentrations in streams; Fig. 8).

Fig. 7. Photos showing students from the Tebughna School in the village of Tyonek participating in research, education programs, and local knowledge sharing with Kachemak Bay National Estuarine Research Reserve staff.
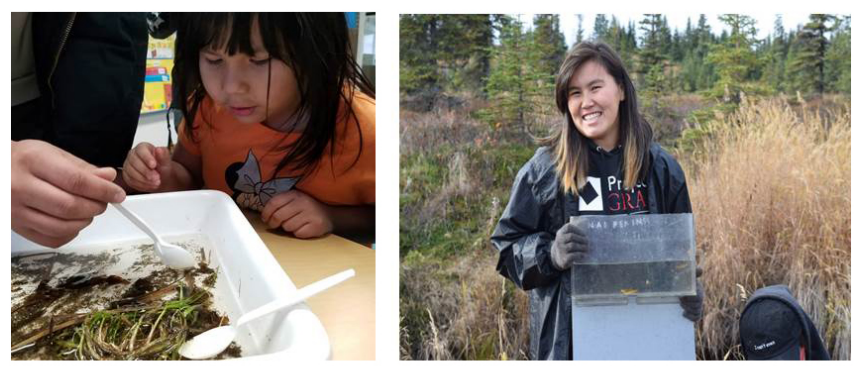

\section{CONCLUSION AND LESSONS LEARNED}

In the Kenai Lowlands, people from many different perspectives and knowledge systems (policy makers, managers, industry, activism, research, cultural sectors) have strong, diverse connections to salmon. There is a complex network of individuals and entities who influence salmon productivity, some of whom manage the lands that support salmon, and others who regulate salmon harvests. Politics around salmon harvest often dominate stakeholder interactions. Competing interests from tribes and commercial and sport fishing persons have been a source of anxiety, especially because recent salmon returns in the area have been low (fish count data for Anchor River chinook 2003-2018 and coho 2004-2011, Ninilchik River chinook 1999-2018, and Deep Creek chinook 1997-2018; ADFG 2020). User conflicts between sport, commercial, and subsistence use of fish, especially salmon, are common. Increasingly, tribes are challenging agency 
Fig. 8. Flowchart demonstrating the iterative flow of information from scientists to stakeholders in a collaborative project to enable meaningful decision-making based on science. This figure was derived from a concept diagram created by Jude Apple, after a Kachemak Bay National Estuarine Research Reserve science collaborative workshop.

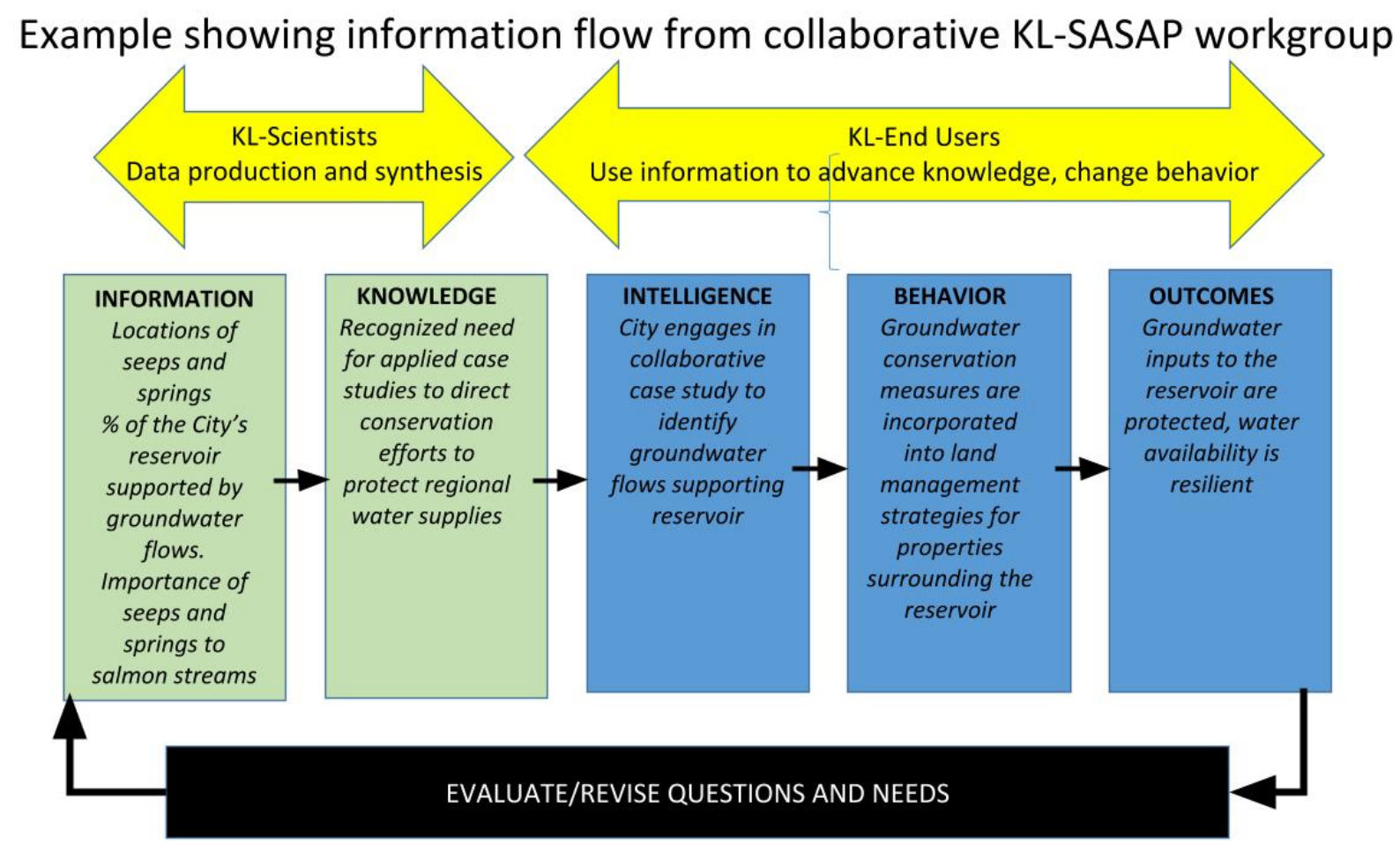

regulations that limit or prevent salmon harvesting (Neyman 2015). There is also controversy around how to manage the landscapes that support salmon streams. Recently, a ballot initiative failed that would have required regulators to assume all waterways have anadromous fish habitat, forcing residential or energy developers to get special permits or prove there are no fish in streams or wetlands that they might affect (Encyclopedia of American Politics, https://ballotpedia.org/Alaska_Ballot_Measure 1, Salmon Habitat Protections and Permits Initiative (2018)).

The KL-SASAP worked under the general premise that stakeholders will make better decisions regarding conserving salmon landscapes if they understand the science that is available. In recent findings from a series of workgroups led by the Alaska Humanities Forum, the most common observation from participants was that people representing each stakeholder group (sector) should participate in facilitated dialogues around how to come together for the continued survival of wild salmon (Bursch et al. 2019). Providing stakeholders with science to inform these dialogues is a beginning. Future work should focus on bringing different stakeholders together for science-based discussions.

The work of the KL-SASAP is focused around engaging stakeholders with science to promote decision-making. We hoped this would lead to conscious restraint, i.e., making informed decisions to limit actions in order to promote conservation (Wilson 2002), as well as policies promoting salmon habitat stewardship. Our approach to provide a collaborative focus on the common problem of sustaining salmon has gained some traction. Initially, the KL-SASAP consisted of the scientists who had been conducting the research, permit and regulatory agency representatives, elected officials, conservation nonprofits, tribal environmental coordinators, and agency planners. Subsequently, important regional decision-makers, who had not been recognized initially but who could be powerful advocates for science-based land-use decisions, became engaged. The North Pacific Fisheries Association purchased land for conserving salmon habitat, Project GRAD provided an avenue for communications with the village of Tyonek, and the Homer Soil and Water District provided a connection with the region's growing agricultural producers. These examples show that concerted, collaborative efforts, and working with a bridging organization such as the KBNERR, can facilitate learning and collaboration across formal institutional and community member boundaries (Garmestani and Allen 2015). KBNERR's role as a transboundary organization was possible because of: (1) longstanding collaborative relationships with scientists from around the country who are committed to developing a robust understanding of how the region's ecosystems function; (2) deep understanding of stakeholder interests, abilities, and needs; (3) the capacity to be flexible in products developed, staff time, travel, and budgets; and (4) the motivation and time to continue building relationships and follow through on new ideas in a collaborative learning framework. 
One of the most salient lessons that came from this project is a deeper understanding that persistence, relationship trust, and time are key aspects of successful collaborative engagement. At the official close-out of the KL-SASAP-funded effort, we could point to outputs from the project, as well as some indicators of longer term outcomes. One year later, outcomes are becoming firmer: lands are being purchased, collaborative partnerships have been formed to submit proposals to extend efforts, more sitebased learning opportunities have been planned, and requests for information that could lead to policy changes are coming from governmental organizations. We are optimistic that, with continued long-term outreach and engagement, there will be more and stronger outcomes in the future.

Meaningful collaborations with stakeholders working on a common problem and with common funding are emerging as a successful strategy for science knowledge transfer to decisionmaking (Arnott et al. 2020). The KL-SASAP provided the initial thrust and trust for collaborations that are currently underway, including groundwater studies, watershed nutrient export to the nearshore, and internship programs with Alaska Native communities. Proposals are being developed for projects around: (1) payment for ecosystem service models to identify further landscape support for salmon, (2) best management practices for restoration from a stream productivity perspective, (3) portfolios of landscapes that encompass the range of habitats important to the diverse life histories of juvenile salmon, and (4) identification of buffers needed to keep landscapes connected for the benefit of salmon stream productivity. We hope that developing these collaborative proposals is increasingly possible because of the trust that was developed during the KL-SASAP process.

Unlike many places where people and salmon live together, Alaska still has thriving wild salmon populations. The watersheds of the Kenai Lowlands are still largely intact and connected but are potentially and increasingly threatened by the high proportion of privately owned land, increasing populations, and climate change. With vested interest from the region's stakeholders for continued collaborations and development of science-based tools and communication products, the people of the Kenai Lowlands have a remarkable opportunity to make decisions that will sustain salmon.

Responses to this article can be read online at: https://www.ecologyandsociety.org/issues/responses. php/11798

\section{Acknowledgments:}

We thank all the workshop participants: Mandy Bernard (Mountains to Sea), Karyn Decino (Kenai River Center), Willy Dunne (Kenai Peninsula Borough Assembly), Ginny Litchfield (Alaska Department of Fish and Game Habitat Division), Catie McCafferty (USCOE), Sue Mauger (Cook Inlet Keeper), Michael Opheim (Seldovia Village Tribe), Phil North (retired EPA), Alice Rademacher (KBNERR), Ian Dutton, Katherine Schake and Sarah Warnock (Nautilus Investing), and Chugachmiut Tribal members. We are especially grateful to case study participants, including Marie McCarty and Denise Jantz
(Kachemak Heritage Land Trust), Malcolm Milne (North Pacific Fisheries Association), Kenny Daher (Project GRAD), Claire Laukitus, Shelly Laukitus, Hannah Heimbuch (Young Fishermen Association), Marcus Mueller (Kenai Peninsula Borough Land Planning), Kyra Wagner (Homer Soil and Water District), Ben Mohr (Cook Inlet Region Inc.), Dana Nelson (KBNERR), and students and staff of the Tebughna school in Tyonek. Funding for the KL-SASAP effort was provided in part by a grant from the Gordon and Betty Moore Foundation through the University of California Santa Barbara to KBNERR (\#KK1753); a grant from the University of Michigan NERR Science Collaborative to the KBNERR (\#NA14NOX4190145); and by the organizations, agencies, and institutions that provided salary support for staff to participate. The manuscript benefitted greatly from two anonymous reviews.

\section{Data Availability:}

Datalcode used were derived from public domain resources.

\section{LITERATURE CITED}

Abdou, M., J. Schäfer, A. Cobelo-García, P. Neira, J. C. J. Petit, D. Auger, J. F. Chiffoleau, and G. Blanc. 2016. Past and present platinum contamination of a major European fluvial - estuarine system: insights from river sediments and estuarine oysters. Marine Chemistry 185:104-110. https://doi.org/10.1016/j. marchem.2016.01.006

Alaska Department of Fish and Game (ADFG). 2019. 2019 Upper Cook Inlet commercial salmon fishery season summary. News release. Alaska Department of Fish and Game, Juneau, Alaska, USA. [online] URL: https://www.adfg.alaska.gov/static/ applications/dcfnewsrelease/1126687650.pdf

Alaska Department of Fish and Game (ADFG). 2020. Fish count database. Alaska Department of Fish and Game, Juneau, Alaska, USA. [online] URL: https://adfg.alaska.gov/sf/FishCounts/

Alaska Department of Labor and Workforce Development (ADLWD). 2020. Alaska population projections 2019-2045. Alaska Department of Labor and Workforce Development, Juneau, Alaska, USA. [online] URL: https://live.laborstats. alaska.gov/pop/projections.cfm

Alexander, R. B., E. W. Boyer, R. A. Smith, G. E. Schwarz, and R. B. Moore. 2007. The role of headwater streams in downstream water quality. Journal of the American Water Resources Association 43(1):41-59. https://doi.org/10.1111/j.1752-1688.2007.00005. $\underline{x}$

Argueta, J. 2018. Salmon and people in the Kenai Lowlands. [map series]. Kachemak Bay National Estuarine Research Reserve and Alaska Center for Conservation Science, Anchorage, Alaska, USA. [online] URL: https://accsmaps.maps.arcgis.com/apps/ MapSeries/index.html?appid=066eb9da45e44db88d3c421 bea611652

Argueta, J., C. Guo, and C. M. Walker. 2018. Salmon and people in the Kenai Lowlands. [video]. Vimeo, New York, New York, USA. [online] URL: https://vimeo.com/239865791

Arnott, J. C., R. J. Neuenfeldt, and M. C. Lemos. 2020. Coproducing science for sustainability: Can funding change knowledge use? Global Environmental Change 60:101979. https:// 


\section{doi.org/10.1016/j.gloenvcha.2019.101979}

Bednarek, A., C. Wyborn, R. Meyer, A. Parris, P. Leith, B. McGreavy, and M. Ryan. 2016. Practice at the boundaries: summary of a workshop of practitioners working at the interfaces of science, policy and society for environmental outcomes. Pew Charitable Trusts, Philadelphia, Pennsylvania, USA. [online] URL: https://www.pewtrusts.org/ /media/assets/2016/07/ practiceattheboundariessummaryofaworkshopofpractitioners.pdf

Beechie, T. J., G. R. Pess, M. M. Pollock, M. H. Ruckelshaus, and P. Roni. 2009. Restoring rivers in the twenty-first century: science challenges in a management context. Pages 697-717 in R. J. Beamish and B. J. Rothschild, editors. The future of fisheries science in North America. Springer, Dordrecht, The Netherlands. https://doi.org/10.1007/978-1-4020-9210-7 33

Berg, E. E., K. McDonnell Hillman, R. Dial, and A. DeRuwe. 2009. Recent woody invasion of wetlands on the Kenai Peninsula Lowlands, south-central Alaska: a major regime shift after 18000 years of wet Sphagnum-sedge peat recruitment. Canadian Journal of Forest Research 39(11):2033-2046. https://doi.org/10.1139/ $\underline{\mathrm{X} 09-121}$

Bisson, P. A., J. B. Dunham, and G. H. Reeves. 2009. Freshwater ecosystems and resilience of Pacific salmon: habitat management based on natural variability. Ecology and Society 14(1):45. https:// doi.org/10.5751/ES-02784-140145

Bryant, M. D., N. D. Zymonas, and B. E. Wright. 2004. Salmonids on the fringe: abundance, species composition, and habitat use of salmonids in high-gradient headwater streams, southeast Alaska. Transactions of the American Fisheries Society 133(6):1529-1538. https://doi.org/10.1577/T03-157.1

Bursch, C., M. Rafferty, and S. Quinn-Davidson. 2019. Mapping Alaska's salmon/people system: challenges and opportunities for change. Alaska Humanities Forum, Anchorage, Alaska, USA. [online] URL: https://63a2ade0-4f43-45eb-8228-40996ff66ade. filesusr.com/ugd/e3ae10 86e0ec9a7fa442e19df4a36d0c4eb729.pdf

Buxton, T. H., J. M. Buffington, D. Tonina, A. K. Fremier, and E. M. Yager. 2015. Modeling the influence of salmon spawning on hyporheic exchange of marine-derived nutrients in gravel stream beds. Canadian Journal of Fisheries and Aquatic Sciences 72(8):1146-1158. https://doi.org/10.1139/cjfas-2014-0413

Callahan, M. K., M. C. Rains, J. C. Bellino, C. M. Walker, S. J. Baird, D. F. Whigham, and R. S. King. 2015. Controls on temperature in salmonid-bearing headwater streams in two common hydrogeologic settings, Kenai Peninsula, Alaska. Journal of the American Water Resources Association 51(1):84-98. https://doi.org/10.1111/jawr.12235

Callahan, M. K., D. F. Whigham, M. C. Rains, K. C. Rains, R. S. King, C. M. Walker, J. R. Maurer, and S. J. Baird. 2017. Nitrogen subsidies from hillslope alder stands to streamside wetlands and headwater streams, Kenai Peninsula, Alaska. Journal of the American Water Resources Association 53(2):478-492. https://doi. org/10.1111/1752-1688.12508

Campeau, A., K. Bishop, M. B. Nilsson, L. Klemedtsson, H. Laudon, F. I. Leith, M. Öquist, and M. B. Wallin. 2018. Stable carbon isotopes reveal soil-stream DIC linkages in contrasting headwater catchments. Journal of Geophysical Research: Biogeosciences 123(1):149-167. https://doi.org/10.1002/2017JG004083

Canuel, E. A., G. S. Brush, T. M. Cronin, R. Lockwood, and A. R. Zimmerman. 2017. Paleoecology studies in Chesapeake Bay: a model system for understanding interactions between climate, anthropogenic activities and the environment. Pages 495-527 in K. Weckström, K. M. Saunders, P. A. Gell, and C. G. Skilbeck, editors. Applications of paleoenvironmental techniques in estuarine studies. Springer, Dordrecht, The Netherlands. https://doi. org/10.1007/978-94-024-0990-1 20

Carr, A., and R. Wilkinson. 2005. Beyond participation: boundary organizations as a new space for farmers and scientists to interact. Society and Natural Resources 18(3):255-265. https:// doi.org/10.1080/08941920590908123

Carson, R. T., W. M. Hanemann, and T. C. Wegge. 2009. A nested logit model of recreational fishing demand in Alaska. Marine Resource Economics 24(2):101-130. https://doi.org/10.1086/ mre.24.2.42731375

Cash, D. W., and S. C. Moser. 2000. Linking global and local scales: designing dynamic assessment and management processes. Global Environmental Change 10(2):109-120. https://doi. org/10.1016/S0959-3780(00)00017-0

City of Homer. 2018. Homer comprehensive plan 2018. City of Homer, Homer, Alaska, USA. [online] URL: https://www. cityofhomer-ak.gov/sites/default/files/fileattachments/planning/ page/30781/2018 homer_comprehensive_plan_final_adopted_version. pdf

David, A. T., C. A. Simenstad, J. R. Cordell, J. D. Toft, C. S. Ellings, A. Gray, and H. B. Berge. 2016. Wetland loss, juvenile salmon foraging performance, and density dependence in Pacific Northwest estuaries. Estuaries and Coasts 39:767-780. https://doi. org/10.1007/s12237-015-0041-5

Davis, J. C., G. A. Davis, and S. Kinard. 2016. Juvenile chinook and coho salmon habitats and distribution in the MatanuskaSusitna borough: 2016. Report for the Matanuska-Susitna Borough, Fish and Wildlife Commission. Aquatic Restoration and Research Institute, Talkeetna, Alaska, USA. [online] URL: http://www.arrialaska.org/reports/Mat-Su\%20Juvenile\%20Salmon \% 20Monitoring $\% 20$ Report $\% 202016$.pdf

Dekar, M. P., R. S. King, J. A. Back, D. F. Whigham, and C. M. Walker. 2012. Allochthonous inputs from grass-dominated wetlands support juvenile salmonids in headwater streams: evidence from stable isotopes of carbon, hydrogen, and nitrogen. Freshwater Science 31(1):121-132. https://doi.org/10.1899/11-016.1

Duarte, C. M., A. Borja, J. Carstensen, M. Elliott, D. KrauseJensen, and N. Marbà. 2015. Paradigms in the recovery of estuarine and coastal ecosystems. Estuaries and Coasts 38:1202-1212. https://doi.org/10.1007/s12237-013-9750-9

Earth Economics. 2013. The natural economy of Alaska's Matanuska-Susitna basin. Unpublished report. Earth Economics, Tacoma, Washington, USA.

Elliott, M., L. Mander, K. Mazik, C. Simenstad, F. Valesini, A. Whitfield, and E. Wolanski. 2016. Ecoengineering with 
ecohydrology: successes and failures in estuarine restoration. Estuarine, Coastal and Shelf Science 176:12-35. https://doi. org/10.1016/j.ecss.2016.04.003

Flaherty, E., K. Kirkpatrick, and T. Snow. 2019. Human and environmental well-being in Alaska's Kachemak Bay watershed: an ecosystem services assessment. Thesis. University of Michigan, Ann Arbor, Michigan, USA. [online] URL: http://hdl.handle. $\underline{\text { net } / 2027.42 / 148820}$

Fleming, I. A., D. L. Bottom, K. K. Jones, C. A. Simenstad, and J. F. Craig. 2014. Resilience of anadromous and resident salmonid populations. Journal of Fish Biology 85(1):1-7. https://doi. org/10.1111/jfb.12429

Foley, K., A. Rosenberger, and F. Mueter. 2015. Effectiveness of single-pass backpack electrofishing to estimate juvenile coho salmon abundance in Alaskan headwater streams. Fisheries Science 81:601-610. https://doi.org/10.1007/s12562-015-0888-1

Freeman, M. C., C. M. Pringle, and C. R. Jackson. 2007. Hydrologic connectivity and the contribution of stream headwaters to ecological integrity at regional scales. Journal of the American Water Resources Association 43(1):5-14. https://doi. org/10.1111/j.1752-1688.2007.00002.x

Gage, M. S., A. Spivak, and C. J. Paradise. 2004. Effects of land use and disturbance on benthic insects in headwater streams draining small watersheds north of Charlotte, NC. Southeastern Naturalist 3(2):345-358. [online] URL: https://www.jstor.org/ $\underline{\text { stable/3878111 }}$

Garmestani, A. S., and C. R. Allen. 2015. Adaptive management of social-ecological systems: the path forward. Pages 255-262 in C. R. Allen and A. S. Garmestani, editors. Adaptive management of social-ecological systems. Springer, Dordrecht, The Netherlands. https://doi.org/10.1007/978-94-017-9682-8

Gracz, M. B., M. F. Moffett, D. I. Siegel, and P. H. Glaser. 2015. Analyzing peatland discharge to streams in an Alaskan watershed: an integration of end-member mixing analysis and a water balance approach. Journal of Hydrology 530:667-676. https://doi.org/10.1016/j.jhydrol.2015.09.072

Gracz, M., and D. Regan. 2005. Wetlands and lowlands of the Kenai Peninsula, Alaska, USA. Kenai Watershed Forum, Fritz Creek, Alaska, USA. [online] URL: https://databasin.org/ datasets/71c3eb791fb941e9acaf71407fc33fe0

Guzy, J., K. Halloran, J. Homyack, and J. D. Willson. 2019. Influence of riparian buffers and habitat characteristics on salamander assemblages in headwater streams within managed forests. Forest Ecology and Management 432:868-883. https://doi. org/10.1016/i.foreco.2018.10.006

Hasselquist, E. M., C. Nilsson, J. Hiältén, D. Jørgensen, L. Lind, and L. E. Polvi. 2015. Time for recovery of riparian plants in restored norther Swedish streams: a chronosequence study. Ecological Applications 25(5):1373-1389. https://doi.org/10.1890/14-1102.1

Hiatt, D. L., C. J. Robbins, J. A. Back, P. K. Kostka, R. D. Doyle, C. M. Walker, M. C. Rains, D. F. Whigham, and R. S. King. 2017. Catchment-scale alder cover controls nitrogen fixation in boreal headwater streams. Freshwater Science 36(3):523-532. https://doi. org/10.1086/692944
Kachemak Bay National Estuarine Research Reserve (KBNERR) and National Oceanic and Atmospheric Administration (NOAA) Coastal Services Center. 2001. Kachemak Bay ecological characterization. NOAA/CSC/20017CD. [computer disc]. Coastal Services Center, Charleston, South Carolina, USA.

King, R. S., C. M. Walker, D. F. Whigham, S. J. Baird, and J. A. Back. 2012. Catchment topography and wetland geomorphology drive macroinvertebrate community structure and juvenile salmonid distributions in south-central Alaska headwater streams. Freshwater Science 31(2):341-364. https://doi.org/10.1899/11-109.1

Klein, E., E. E. Berg, and R. Dial. 2005. Wetland drying and succession across the Kenai Peninsula Lowlands, south-central Alaska. Canadian Journal of Forest Research 35(8):1931-1941. https://doi.org/10.1139/X05-129

Kozlowski, D. F., R. K. Hall, S. R. Swanson, and D. T. Heggem. 2016. Linking management and riparian physical functions to water quality and aquatic habitat. Journal of Water Resources and Protection 8(8):797-815. https://doi.org/10.4236/jwarp.2016.88065

Lagrue, C., A. A. Besson, and A Lecerf. 2018. Small alteration big impacts: effects of small-scale riparian forest management on host-parasite dynamics in streams. Journal of Helminthology 92 (1):64-73. https://doi.org/10.1017/S0022149X16000936

Lamberti, G. A., D. T. Chaloner, and A. E. Hershey. 2010. Linkages among aquatic ecosystems. Journal of the North American Benthological Society 29(1):245-263. https://doi. org/10.1899/08-166.1

Lecerf, A., C. Evangelista, J. Cucherousset, and A. Boiché. 2016. Riparian overstory-understory interactions and their potential implications for forest-stream linkages. Forest Ecology and Management 367:112-119. https://doi.org/10.1016/j.foreco.2016.02.031

Ledesma, J. L. J., M. N. Futter, M. Blackburn, F. Lidman, T. Grabs, R. A. Sponseller, H. Laudon, K. H. Bishop, and S. J. Köhler. 2018. Towards an improved conceptualization of riparian zones in boreal forest headwaters. Ecosystems 21:297-315. https:// doi.org/10.1007/s10021-017-0149-5

Ledesma, J. L. J., M. N. Futter, H. Laudon, C. D. Evans, and S. J. Köhler. 2016. Boreal forest riparian zones regulate stream sulfate and dissolved organic carbon. Science of the Total Environment 560-561:110-122. https://doi.org/10.1016/j. scitotenv.2016.03.230

Leppi, J. C., D. J. Rinella, R. R. Wilson, and W. M. Loya. 2014. Linking climate change projections for an Alaskan watershed to future coho salmon production. Global Change Biology 20 (6):1808-1820. https://doi.org/10.1111/gcb.12492

Lidman, F., Å. Boily, H. Laudon, and S. J. Köhler. 2017. From soil water to surface water - how the riparian zone controls element transport from a boreal forest to a stream. Biogeosciences 14:3001-3014. https://doi.org/10.5194/bg-14-3001-2017

Little, C. J., and F. Altermatt. 2018. Landscape configuration alters spatial arrangement of terrestrial-aquatic subsidies in headwater streams. Landscape Ecology 33:1519-1531. https://doi. org/10.1007/s10980-018-0678-0 
Mauger, S., R. Shaftel, J. C. Leppi, and D. J. Rinella. 2017. Summer temperature regimes in southcentral Alaska streams: watershed drivers of variation and potential implications for Pacific salmon. Canadian Journal of Fisheries and Aquatic Science 74(5):702-715. https://doi.org/10.1139/cjfas-2016-0076

McClure, M. M., S. M. Carlson, T. J. Beechie, G. R. Pess, J. C. Jorgensen, S. M. Sogard, S. E. Sultan, D. M. Holzer, J. Travis, B. L. Sanderson, M. E. Power, and R. W. Carmichael. 2008. Evolutionary consequences of habitat loss for Pacific anadromous salmonids. Evolutionary Applications 1(2):300-318. https://doi.org/10.1111/j.1752-4571.2008.00030.x

Mitchell, N. L., and G. A. Lamberti. 2005. Responses in dissolved nutrients and epilithon abundance to spawning salmon in southeast Alaska streams. Limnology and Oceanography 50 (1):217-227. https://doi.org/10.4319/10.2005.50.1.0217

Muller, I., M. Delisle, M. Ollitrault, and I. Bernez. 2016. Responses of riparian plant communities and water quality after 8 years of passive ecological restoration using a BACI design. Hydrobiologia 781:67-79. https://doi.org/10.1007/s10750-015-2349-3

Murphy, M. L. 1995. Forestry impacts on freshwater habitat of anadromous salmonids in the Pacific Northwest and Alaska requirements for protection and restoration. NOAA Coastal Ocean Program Decision Analysis Series 7. National Oceanic and Atmospheric Administration Coastal Ocean Office, Silver Spring, Maryland, USA. [online] URL: https://repository.library.noaa. gov/view/noaa/2926

Nadeau, T.-L., and M. C. Rains. 2007a. Hydrological connectivity of headwaters to downstream waters: introduction to the featured collection. Journal of the American Water Resources Association 43(1):1-4. https://doi.org/10.1111/j.1752-1688.2007.00001.X

Nadeau, T.-L., and M. C. Rains. 2007b. Hydrological connectivity between headwater streams and downstream waters: how science can inform policy. Journal of the American Water Resources Association 43(1):118-133. https://doi.org/10.1111/j.1752-1688.2007.00010. $\underline{\mathrm{X}}$

Neyman, J. 2015. Ninilchik files fish lawsuit — Tribal Council alleges mismanagement prevented salmon subsistence harvest opportunity. Redoubt Reporter November 11, 2015. [online] URL: https://redoubtreporter.wordpress.com/2015/11/11/ninilchikfiles-fish-lawsuit-tribal-council-alleges-mismanagement-preventedsalmon-subsistence-harvest-opportunity/

Olson, D. H., and K. M. Burnett. 2009. Design and management of linkage areas across headwater drainages to conserve biodiversity in forest ecosystems. Forest Ecology and Management 258(S):S117-S126. https://doi.org/10.1016/j.foreco.2009.04.018

Palmer, M., E. Bernhardt, E. Chornesky, S. Collins, A. Dobson, C. Duke, B. Gold, R. Jacobson, S. Kingsland, R. Kranz, M. Mappin, M. L. Martinez, F. Micheli, J. Morse, M. Pace, M. Pascual, S. Palumbi, O. J. Reichman, A. Simons, A. Townsend, and M. Turner. 2004. Ecology for a crowded planet. Science 304 (5675):1251-1252. https://doi.org/10.1126/science.1095780

Richardson, D. P., A. E. Kohler, M. Hailemichael, and B. P. Finney. 2017. The fate of marine-derived nutrients: tracing $\delta^{13} \mathrm{C}$ and $\delta^{15} \mathrm{~N}$ through oligotrophic freshwater and linked riparian ecosystems following salmon carcass analog additions. Canadian Journal of Fisheries and Aquatic Sciences 74(1):41-55. https://doi. org/10.1139/cjfas-2015-0500

Rinella, D. J., M. S. Wipfli, C. M. Walker, C. A. Stricker, and R. A. Heintz. 2013. Seasonal persistence of marine-derived nutrients in south-central Alaskan salmon streams. Ecosphere 4(10):1-18. https://doi.org/10.1890/ES13-00112.1

Robbins, C. J., R. S. King, A. D. Yeager, C. M. Walker, J. A. Back, R. D. Doyle, and D. F. Whigham. 2017. Low-level addition of dissolved organic carbon increases basal ecosystem function in a boreal headwater stream. Ecosphere 8(4):e01739. http://dx.doi. org/10.1002/ecs 2.1739

Robbins, C. J., A. D. Yeager, S. C. Cook, R. D. Doyle, J. R. Maurer, C. M. Walker, J. A. Back, D. F. Whigham, and R. S. King. 2020. Low-level dissolved organic carbon subsidies drive a trophic upsurge in a boreal stream. Freshwater Biology 65(5):920-934. https://doi.org/10.1111/fwb.13478

Roberts, B. J., P. J. Mulholland, and J. N. Houser. 2007. Effects of upland disturbance and instream restoration on hydrodynamics and ammonium uptake in headwater streams. Journal of the North American Benthological Society 26(1):38-53. https://doi.org/10.1899/0887-3593(2007)26[38:EOUDAI]2.0.CO;2

Roon, D. A., M. S. Wipfli, and J. J. Kruse. 2018. Riparian defoliation by the invasive green alder sawfly influences terrestrial prey subsidies to salmon streams. Journal of Freshwater Fish 27 (4):963-975. https://doi.org/10.1111/eff.12407

Rosenfeld, J., M. Porter, and E. Parkinson. 2000. Habitat factors affecting the abundance and distribution of juvenile cutthroat trout (Oncorhynchus clarki) and coho salmon (Oncorhynchus kisutch). Canadian Journal of Fisheries and Aquatic Sciences 57 (4):766-774. https://doi.org/10.1139/f00-010

Samways, K. M., Z. J. Quiñones-Rivera, P. R. Leavitt, and R. A. Cunjak. 2015. Spatiotemporal responses of algal, fungal, and bacterial biofilm communities in Atlantic rivers receiving marinederived nutrient inputs. Freshwater Science 34(3):881-896. https:// doi.org/10.1086/681723

Schmidt, D. C., S. R. Carlson, G. B. Kyle, and B. P. Finney. 1998. Influence of carcass-derived nutrients on sockeye salmon productivity of Karluk Lake, Alaska: importance in the assessment of escapement goal. North American Journal of Fisheries Management 18(4):743-763. https://doi.org/10.1577/1548-8675 (1998)018<0743:IOCDNO>2.0.CO;2

Schoen, E. R., M. S. Wipfli, E. J. Trammell, D. J. Rinella, A. L. Floyd, J. Grunblatt, M. D. McCarthy, B. E. Meyer, J. M. Morton, J. E. Powell, A. Prakash, M. N. Reimer, S. L. Stuefer, H. Toniolo, B. M. Wells, and F. D. W. Witmer. 2017. Future of Pacific salmon in the face of environmental change: lessons from one of the world's remaining productive salmon regions. Fisheries 42 (10):538-553. https://doi.org/10.1080/03632415.2017.1374251

Schwörer, T. 2014. Attitudes towards land use and development in the Mat-Su: empirical evidence on economic values of ecosystem services. ISER working paper. Institute of Social and Economic Research, University of Alaska Anchorage, Anchorage, Alaska, USA. [online] URL: http://iser.uaa.alaska.edu/Publications/2014_04_25- 


\section{$\underline{\text { SchwoererMat-Su2040FuturesSurvey.pdf }}$}

Shaftel, R. S., R. S. King, and J. A. Back. 2011. Breakdown rates, nutrient concentrations, and macroinvertebrate colonization of bluejoint grass litter in headwater streams of the Kenai Peninsula, Alaska. Journal of the North American Benthological Society 30 (2):386-398. https://doi.org/10.1899/10-086.1

Shaftel, R. S., R. S. King, and J. A. Back. 2012. Alder cover drives nitrogen availability in Kenai lowland headwater streams, Alaska. Biogeochemistry 107:135-148. https://doi.org/10.1007/s10533-010-9541-3

Simenstad, C. A, K. L. Fresh, and E. O. Salo. 1982. The role of Puget Sound and Washington coastal estuaries in the life history of Pacific salmon: an unappreciated function. Pages 343-364 in V. S. Kennedy, editor. Estuarine comparisons: proceedings of the sixth biennial international estuarine research conference, Gleneden Beach, Oregon, November 1-6, 1981. Academic Press, New York, New York, USA. https://doi.org/10.1016/B978-0-12-404070-0.50026-0

Sloat, M. R., G. H. Reeves, and K. R. Christiansen. 2017. Stream network geomorphology mediates predicted vulnerability of anadromous fish habitat to hydrologic change in southeast Alaska. Global Change Biology 23(2):604-620. https://doi. org/10.1111/gcb.13466

Tanacredi, J. T., M. P. Schreibman, and K. McDonnell. 2016. Questioning ecosystem assessment and restoration practices in a major urban estuary: perpetuating myths of degradation in spite of the facts. Journal of Environmental Science and Engineering $B$ 5:78-108. https://doi.org/10.17265/2162-5263/2016.02.003

Vasslides, J. M., and O. P. Jensen. 2016. Fuzzy cognitive mapping in support of integrated ecosystem assessments: developing a shared conceptual model among stakeholders. Journal of Environmental Management 166:348-356. https://doi.org/10.1016/ j.jenvman.2015.10.038

Vizza, C., B. L. Sanderson, H. J. Coe, and D. T. Chaloner. 2017. Evaluating the consequences of salmon nutrients for riparian organisms: linking condition metrics to stable isotopes. Ecology and Evolution 7(5):1313-1324. https://doi.org/10.1002/ece3.2697

Wagner, M. A., and J. D. Reynolds. 2019. Salmon increase forest bird abundance and diversity. Plos One 14(2):e0210031. https:// doi.org/10.1371/journal.pone.0210031

Walker, C. M., R. S. King, D. F. Whigham, and S. J. Baird. 2012. Landscape and wetland influences on headwater stream chemistry in the Kenai lowlands, Alaska. Wetlands 32:301-310. https://doi.org/10.1007/s13157-011-0260-x

Wallace, J. B., S. L. Eggert, J. L. Meyer, and J. R. Webster. 2015. Stream invertebrate productivity linked to forest subsidies: 37 stream-years of reference and experimental data. Ecology 96 (5):1213-1228. https://doi.org/10.1890/14-1589.1

Waples, R. S., T. Beechie, and G. R. Pess. 2009. Evolutionary history, habitat disturbance regimes, and anthropogenic changes: What do these mean for resilience of Pacific salmon populations? Ecology and Society 14(1):3. https://doi.org/10.5751/ES-02626-140103

Warren, D. R., W. S. Keeton, P. M. Kiffney, M. J. Kaylor, H. A.
Bechtold, and J. Magee. 2016. Changing forests-changing streams: riparian forest stand development and ecosystem function in temperate headwaters. Ecosphere 7(8):e01435. https:// doi.org/10.1002/ecs2.1435

Whigham, D. F., C. M. Walker, R. S. King, and S. J. Baird. 2012. Multiple sales of influence on wetland vegetation associated with headwater streams in Alaska, USA. Wetlands 32:411-422. https:// doi.org/10.1007/s13157-012-0274-Z

Whigham, D. F., C. M. Walker, J. Maurer, R. S. King, W. Hauser, S. Baird, J. A. Keuskamp, and P. J. Neale. 2017. Watershed influences on the structure and function of riparian wetlands associated with headwater streams - Kenai Peninsula, Alaska. Science of the Total Environment 599-600:124-134. https://doi. org/10.1016/j.scitotenv.2017.03.290

Wilson, E. O. 2002. The future of life. Knopf, New York, New York, USA.

Wipfli, M. S., J. S. Richardson, and R. J. Naiman. 2007. Ecological linkages between headwaters and downstream ecosystems: transport of organic matter, invertebrates, and wood down headwater channels. Journal of the American Water Resources Association 43(1):72-85. https://doi.org/10.1111/j.1752-1688.2007.00007. $\underline{\mathrm{X}}$

Workman, W. B., and K. W. Workman. 2010. The end of the Kachemak tradition on the Kenai Peninsula, southcentral Alaska. Arctic Antrhopology 47(2):90-96. [online] URL: https:// www.jstor.org/stable/25780687

Zedler, J. B. 2017. What's new in adaptive management and restoration of coats and estuaries? Estuaries and Coasts 40:1-21. https://doi.org/10.1007/s12237-016-0162-5 